Salvation Army, through Colonel D.
Anderson, 101 Queen Victoria Street, London E.C.1., the United Society for the Propagation of the Gospel, through Dr. Kathleen Wright, 15 Tufton Street, London SWIP 3QQ, and Oxfam through Dr. Tim Lusty, Upper Whitley Farm, Cumnor, Oxford. All will welcome inquiries.

Secondly, I obtained, as have others, much help, interest, and kindness in Dr. David Morley's department at the Institute of Tropical Child Health. They have a useful library of books, tapes, and slides, much expertise, and very useful contacts. A few days of orientation spent there is invaluable. Contact Miss Margaret Woodland, c/o the Institute of Child Health, 30 Guildford Street, London, WC1N 1EH, tel. 01-837 4825.-I am, etc.,

Whitstable

Michael VaILe

\section{Intratracheal Anaesthesia}

SIR,-In your leading article on "Postintubation Granuloma" (10 November, p. $313)$ it is stated that intratracheal anaesthesia was introduced ir the 1930s.

It is generally held that the method was brought into this country in 1912 by the Liverpool surgeon Mr. R. E. Kelly. ${ }^{1}$ When an anaesthetic clerk in 1917 I myself watched Mr. H. E. G. Boyle use the technique for a thyroid operation. By the end of the first world war, Dr. (now Sir Ivan) Mag:ll and Dr. E. S. Rowbotham were regularly using naso-and orotracheal tubes for insufflation anaesthesia, thus enabling Sir Harold Gillies and his team to develop their splendid work on plastic surgery for facial wounds at the Queen's Hospital at Sidcup. By 1923 endotracheal anaesthesia was commonplace at Barts for suitable operations.

I would therefore suggest that it is hardly fair to ignore the sterling work carried out by the above-mentioned pioneers and others in this field.-I am, etc.,

London N.6

C. LANGTON HewER 1 Kelıy, R. E., British Medical fournal, 1912, 2 ,

SIR,-As an enthusiastic protagonist of endotracheal anaesthesia for some 50 years I must consider myself lucky not to have caused the post-intubation granuloma referred to in your leading article (10 November, p. 313). Nevertheless, considering the extensive use of the method in many branches of surgery it is perhaps timely that some notice should be taken of the occasional hazards associated with intubation of the larynx and trachea.

No doubt these hazards have diminished markedly since the introduction of muscular relaxants. But they do exist. The patient who suffers from a sore throat following an unnecessary intubation has just cause for complaint. In this context mention may be made of the effects on the tracheal mucusa of overinflation of the cuffs now commonly used on endotracheal tubes. Judging from advertisements in the September issue of Anesthesio$\log y$ there is apparently a demand for lowpressure cuffs in the U.S.A.

Instrumentation, including intubation, involves the risk of trauma, a risk which should be justified by the requirements of the operation and not merely to ensure easy control of the patient's airway by the anaesthetist. It is sometimes forgotten that this can be achieved with a pharyngeal airway or even by manual support of the patient's jaw. I know one consultant anaesthetist who avoids intubation for ophthalmic operations and I know two surgeons who object to intubation for tonsilectomy in children. At the same time I have heard of an infant being intubated for circumcision. I have had the good fortune in the past to work with a famous surgeon who specialized in prostatectomy and never intubated one of his patients.

Has the old art of anaesthesia been lost entirely? - I am, etc.,

London W.1

IVAN W. MAGILL

\section{Fall-out from Bomb Tests}

SIR,-Dr. M. A. Denborough's letter (6 October, p. 46) illustrates some of the difficulties referred to in your leading article (8 September, p. 510) which make calculations of likely numbers of casualties from fall-out such an uncertain guide to thought and action.

First, the facts may be misunderstood. Radioactive isotopes may indeed dissipate their energy in a small volume of tissue, but this is automatically taken account of when estimating radiation doses: a millirad is a unit of energy absorption per gramme. Radiation exposures from atmospheric bomb tests are not qualitatively different in their effects from exposures to natural background, and this is in fact the premise for all calculations of expected numbers of cases of leukaemia and of thyroid cancer, etc., including those cited by Dr. Denborough.

Second, "the maximum published figures for radiation risks" were used in these calculations. If one wishes to ban something dangerous, is it more persuasive to use a maximum estimate or something more realistic?

Third, radiation effects are outside most people's experience so that an appeal has to be made to "authority." The only cited reference for the numbers of Australian casualties to be expected from French bomb tests was an Australian Parliamentary Paper, 1 which presents conclusions but no supporting bibliography of any kind. The reader has no way of checking the calculations, and internal evidence suggests that checking is needed-the risk coefficient used for leukaemia seems to have been about 100 cases per million per rad, rather out of line with what is generally accepted.

Fourth, the assumption of direct proportionality of known biological effects to radiation is not without difficulties for cancer induction. The Parliamentary Paper seems to use an average risk coefficient of around 100 cases of thyroid cancer per million persons per rad, which will have been derived from the experience of individuals receiving tens or hundreds of rads to the thyroid. If direct proportionality is correct, background radiation must be responsible for perhaps 10 cases per million per year. This is close to the natural death rate for thyroid cancer in the U.K. and thus seems much too high, even when allowance is made for the very long survival after diagnosis of radiation-induced thyroid cancer in man.

Fifth, since there are no known qualitative differences between the risks from different kinds of radiations, the same method of risk calculation is as valid for medical uses of radiation as for bomb fall-out. If routine diagnostic exposures are made in the same way in Australia as in Britain so that the associated radiation dosage is similar (which must be roughly true) then the cancer risk in Australians for which Australian doctors are responsible will be 100 times greater than the cancer risk from the fall-out from all the French weapon tests. Why is this not a compelling argument against further use of medical radiation? Clearly either because we do not accept the risk calculations or, alternatively, because we believe that the benefits outweigh the risks. The arguments about bomb tests are not really about whether one or 10 or 100 cases of induced malignant disease are enough to justify their banning but about the magnitude of the benefits which they bring and to whom.

I hope no one will think that I am questioning Dr. Denborough's sincerity or that they can deduce what my personal views may be about bomb tests.-I am, etc.,

Oxford

R. H. MOLE

1 Biological Effects of Nuclear Explosion Fallout. Report of a Meeting between Australian and French Scientists, Parliamentary Paper No. 29. 1973.

\section{Traveller's Ankle and \\ Traveller's Back}

SIR,-Traveller's ankle (Mr. H. Daintree Johnson, 14 July, p. 109, and 3 November, p. 300) and traveller's back would seem to stem from the same cause-sitting in a restricted space for long periods. Though many advertisements continue to inform us that seats for planes, trains, coaches, and cars are designed on orthopaedic principles, that influence ceases at knee level and the commercial need to pack occupants into a limited space takes over and is met by discounting the importance of structures below the knee in the correct sitting posture. Traveller's back may well start from the lack of below-knee comfort; it first starts in the buttock and progresses to such lumbar discomfort as finally to force the car driver and particularly his rear-seat passengers to leave their car to "stretch their legs." Motorway service areas must owe much of their custom to this need.

Some years ago I persuaded a friendly car designer to build a comfortable and solid support for my left foot at the left side of the clutch pedal and relate it to my seated position. This not only allowed exercise to my left foot, but intermittent pressure on it relieved my buttock discomfort and allowed a temporary change in the position of the lumbar spine, giving more comfort than anything previously tried.

I would be interested to know just how long the average healthy person can sit in the restricted space now generally provided and still maintain physical and mental efficiency. In this regard current and common industrial practice in air travel is in- 